\title{
A APLICAÇÃO DO DESCARTE PRODUTIVO DA EMPRESA PHANDA NO DESENVOLVIMENTO DE UM NOVO PRODUTO
}

\author{
Talita Kohls (Católica de Santa Catarina); \\ Nelson Martins de Almeida Netto, M.Sc. (Católica de Santa Catarina)
}

\section{INTRODUÇÃO}

O mercado nacional que compreende o uso de madeira como matéria prima, ocupa cerca de 19\% da economia. Conforme aponta IBA (2014), há um consumo total de 6,1 milhões de metros cúbicos em tora, retirados da Amazônia anualmente. Dentro deste total $21 \%$ é destinado ao uso de indústrias de produtos de madeira.

Analisando a produção da empresa Phanda - Pisos e Molduras de Madeira, em Jaraguá do Sul, percebe-se que são utilizadas madeiras nobres, entre elas estão a Imbuia, Jequitibá e Cumaru. Durante a fabricação são geradas sobras de madeira pequenas demais para serem transformadas em

Compreendendo a possibilidade de reutilização objetivou-se: Por meio do design, desenvolver um produto a partir de sobras de matéria prima (madeira), da empresa Phanda, atentando para o seu segmento.

A metodologia projetual adotada foi a de Löbach (2011) desenvolvendo-se completamente as quatro etapas propostas pelo autor: A preparação, a Geração, a Avaliação e a Realização.

\section{ANÁLISE DA SITUAÇÃO E DESENVOLVIMENTO}

Conforme Löbach (2011), o ponto de partida de processo de design está na análise do problema, todos os dados coletados possuem sua importância na construção da solução do problema. Neste sentido verificou-se na empresa, especificamente seu parque industrial, que o foco é a produção de acabamentos de construção civil, como pisos, decks, revestimentos, luminárias e principalmente produção de portas. Levantou-se ainda que a produção mensal chega a resultar em até $1 \mathrm{~m} 3$ de resíduo por mês, com grande variedade de tipos de madeira e dimensões dos pedaços.

Na Figura 01, ilustra-se à esquerda o local e o material descartad o e a direita o material já selecionado e preparado para a reutilização.

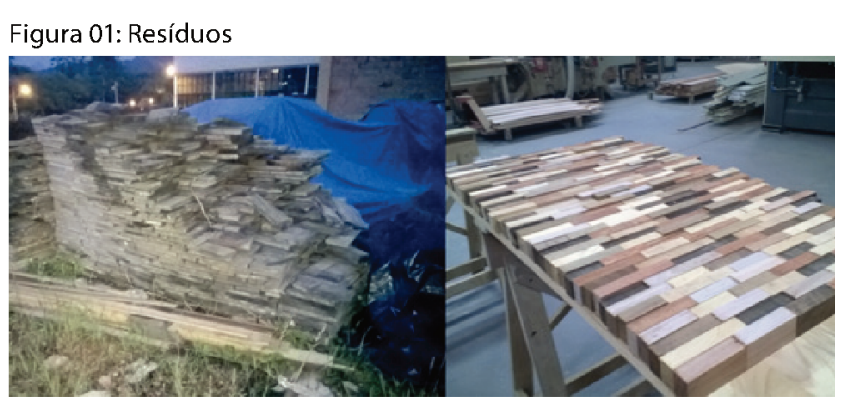

Fonte: Kohls; Almeida Netto, 2014

Utilizando-se a ferramenta de criatividade de Bonsiepe (2012), a Criação Sistemática de Variantes, resultou neste modelo pois a empresa possui produtos de produção em série, as sobras provindas destes produtos já possuem algumas dimensões similares, sendo possível o desenvolvimento de placas sem a necessidade de cortes especiais nas sobras.

Segundo Manzini (2005), é possível classificar reutilização como o segundo uso de produtos ou partes do mesmo, previamente descartados ou eliminados. Para tal processo, os resíduos devem ser recolhidos e encaminhados ao mesmo uso ou a outro com menos requisitos.

Na etapa de Avaliação definiu-se um modelo, retratado na Figura 02, capaz de ser produzido na empresa e que acrescenta inovação à linha de produtos oferecidos pela mesma.

Figura 02: Mesa de Centro

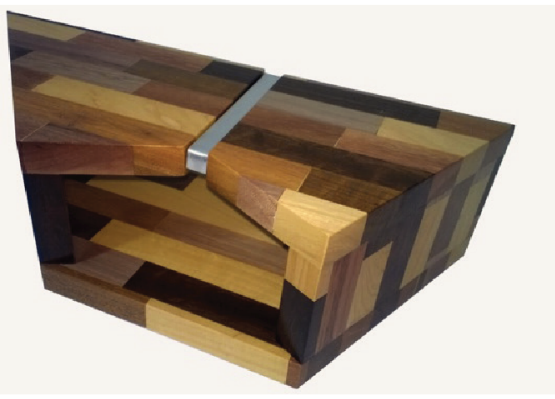

Fonte: Kohls, 2014 
Os resultados alcançados com a pesquisa e o desenvolvimento da placa e do produto provaram ser possível a reutilização das sobras de produção no desenvolvimento de novos produtos, utilizando apenas a tecnologia disponível na empresa.

\section{REFERÊNCIAS}

BONSIEPE, G. Design: como prática de projeto. São Paulo: Blucher, 2012. 214p.

IBA - INDUSTRIA BRASÍLEIRA DE ÁRVORES. Dados e fatos. Disponível em: <http://www.iba.org/ web/pt/dados-fatos/>. Acesso em: 01 de jun. de 2014.

LÖBACH, B. Design industrial: bases para a confirmação dos produtos industriais. São Paulo: Edgard Blücher, 2011.

MANZINI, E. Design para a inovação social e sustentabilidade: comunidades criativas, organizações colaborativas e novas redes projetuais, Rio de Janeiro: E-Papers, 2008. 